\title{
The forbidden fruit: using the mother tongue in a Bogota university EFL programme *
}

\author{
La fruta prohibida: el uso de la lengua materna en \\ el programa de inglés como lengua extranjera, en \\ una universidad de Bogotá.
}

\author{
Jill Fortune \\ Language Department Coordinator \\ Universidad Externado de Colombia \\ Bogotá, Colombia \\ E-mail: jill.fortune01@gmail.com
}

Received: 26 - July - 12 / Accepted: 13 - Octobe $\mathrm{r}-12$

\begin{abstract}
The current debate on the use of the mother tongue in the foreign language classroom has led to a wide array of literature being written on the subject. While this can be enlightening, it can also cause confusion and anxiety among teachers when faced with the question of whether or not it is acceptable to use the L1 in class. This paper analyses current perceptions and practices in terms of $L 1$ use among teachers and students in the EFL and ESL settings, based on the hypothesis that the use of the L1 to some degree could be beneficial to EFL learners. Teacher and student activity and opinions are analysed through surveys and interviews before being compared and contrasted with classroom reality through live observation. The findings confirm that $L 1$ use could indeed be beneficial to EFL learners, particularly at the lower levels of language proficiency, but that teachers may need to revisit their reasons for using the $L 1$, as well as their repertoire of pro-L2-use strategies.
\end{abstract}

Key words: mother tongue, EFL, ESL, L2 teaching strategies, English-Only Rule, L1 prohibition

\section{Resumen}

Hay mucha literatura actual sobre el debate del uso de la lengua materna en la clase de lengua extranjera. Mientras esto puede ser esclarecedor, también puede llegar a causar confusión y ansiedad entre profesores, al preguntarse si es aceptable o no utilizar la primera lengua en clase. Este artículo analiza las percepciones y prácticas actuales en cuanto al uso de la primera lengua entre profesores y estudiantes en los contextos de inglés como lengua extranjera y como segunda lengua, basado en la hipótesis que su uso, hasta cierto punto, podría ser beneficioso a los estudiantes de inglés como lengua extranjera. La actividad y las opiniones de profesores y estudiantes se analizan a través de encuestas y entrevistas, y esta información se compara con la realidad de la clase por medio de observación en vivo. Los resultados confirman que el uso de la primera lengua puede ser beneficioso a los estudiantes de inglés como lengua extranjera, especialmente en los niveles más bajos de competencia, pero que los profesores quizás tengan que volver a considerar sus razones por usarla, además de sus estrategías de enseñanza en la segunda lengua.

Palabras claves: lengua materna, inglés como lengua extranjera, inglés como segunda lengua, estrategias de enseñanza en la segunda lengua, Regla de Sólo Inglés, prohibición de la primera lengua.

\section{Résumé}

II y a beaucoup de littérature sur le débat actuel sur l'usage de la langue maternelle dans le cours de langue étrangère. Tandis qu'il peut être éclairant, il peut aussi provoquer de la confusion et de l'anxiété chez les formateurs, en se demandant s'il est acceptable ou non utiliser la langue maternelle dans le cours. Cet article analyse les perceptions et les pratiques actuelles quant à l'usage de la langue maternelle par les 
formateurs et les étudiants dans les contextes de l'anglais comme langue étrangère, fondé sur l'hypothèse des bienfaits de son usage, jusqu'à certain point, pour les étudiants de l'anglais comme langue étrangère. L'activité et les avis des formateurs et des étudiants sont analysés à travers d'enquêtes et d'entretiens et cette information est comparée avec la réalité de la salle de classe au moyen de l'observation directe. Les résultats confirment que l'usage de la langue maternelle peut être profitable pour les étudiants de l'anglais comme langue étrangère, en particulier dans les niveaux les plus bas de compétence, mais les formateurs devront peut-être reconsidérer leurs motifs pour l'utiliser et leurs stratégies d'enseignement dans la seconde langue.

Mots clés: langue maternelle, anglais comme langue étrangère, anglais comme seconde langue, Règle anglais seulement, interdiction de la langue maternelle.

\section{Resumo}

Existe muita literatura sobre o atual debate sobre o uso da língua materna na aula de língua estrangeira. Enquanto isto pode ser esclarecedor, também pode chegar a causar confusão e ansiedade entre professores, ao perguntar-se si é aceitável ou não utilizar a primeira língua em aula. Este artigo analisa as percepções e práticas atuais em quanto ao uso da primeira língua entre professores e estudantes nos contextos de inglês como língua estrangeira e como segunda língua, baseado na hipótese que seu uso, até certo ponto, poderia ser benéfico aos estudantes de inglês como língua estrangeira. A atividade e as opiniões de professores e estudantes se analisam através de pesquisas e entrevistas, e esta informação se comparam com a realidade da aula por meio de observação em vivo. Os resultados confirmam que o uso da primeira língua pode ser benéfico aos estudantes de inglês como língua estrangeira, especialmente nos níveis mais baixos de competência, mas que os professores talvez tenham que voltar a considerar suas razões por usá-la, além de suas estratégias de ensino na segunda língua.

Palavras chaves: língua materna, inglês como língua estrangeira, inglês como segunda língua, estratégias de ensino na segunda língua, Regra de Só Inglês, proibição da primeira língua

* This article reports some findings of the research project titled: L2 versus L1 in the Colombian private university: how, when and to what degree should each be used in the ongoing quest for EFL improvement? Carried out at Universidad Externado de Colombia between July 2011 and January 2012. 


\section{Introduction}

Students' refusal to use the L2 in the classroom "can drive teachers wild" (Harmer, 2001, p. 131), and the private university in Bogota considered here is no exception. Such exasperation prompted this research, in an attempt to break down the present "mother tongue taboo" (Deller, 2008, p. 3) in Colombian EFL.

It is worth noting that while the aim of the research was to guide staff and students in a specific university, the findings should also be useful to other institutions in similar contexts.

The current debate regarding the use of students' mother tongue in the language classroom (Ferrer, 2011) has been raging for some time; even back in the nineteen-eighties, Atkinson claimed "total prohibition" of the student L1 in the classroom to have become "unfashionable" (1987, p. 241). As Harmer states, while today many do still strongly defend the 'EOR' (English-only rule), there are also ever more methodologists and practitioners who are considering instead the possible benefits of using students' L1 in class (2007, p. 132).

\section{Local Context}

The principal focus of this research is a private university in Bogota, Colombia, where English is taught as a foreign language to undergraduate students as an obligatory subject in various degree programmes. The EFL courses run from $\mathrm{A} 1$ to $\mathrm{B} 2+$ of the CEFR (Council of Europe, 2001), and groups include students from various faculties.

Classes include students of both sexes, and most are 16-24 years old. Most share a similar (privileged) socioeconomic background, but while some have spent primary and secondary education in so-called "bilingual" (Spanish-
English) schools, others have enjoyed less exposure to English previously.

The great majority of students are Colombian, meaning that the L1 is almost $100 \%$ homogenous (Spanish), with some exceptional cases of indigenous community members and foreign exchange students who speak Spanish as an additional language.

The EFL staff includes over 30 teachers of different nationalities and mother tongues, including Colombian nationals. Teachers whose L1 is not Spanish supposedly have at least a working knowledge of this language.

While there is no official departmental policy regarding student L1 use in class, there does exist a general feeling at the institutional level that EFL classrooms should constitute an 'Englishonly environment', to provide students with the maximum exposure possible to the L2.

\section{International Context}

The second institution involved in this research is a public university in England, where English is taught as a second language to students of varying degree programs.

Groups are heterogeneous in terms of age, gender, socioeconomic background, nationality and mother tongue. Students are classified into three groups, aimed roughly at bands 5,0-5,5, 6,0 and $6,5+$ on the Cambridge IELTS examination scale (all considered to be within the B2 band of the CEFR).

All three teachers involved in this ESL programme at the time of study were native English speakers. Departmental policy dictates that students should not use their mother tongue in class.

\section{Research Aim}

Following the pro-L1 Grammar-Translation method of the nineteenth century, the Direct 
Method took over as the new ELT trend, and prohibited the mother tongue from the language classroom (Harmer, 2007, p. 63-4). Since then, an array of literature has been published regarding the use (and abuse) of the L1 in class. While this acknowledges the importance of the matter in language learning and teaching, so much debate has also helped create uncertainty and anxiety among teachers and administrators. The aim of this project is to guide students and teachers through the myriad opinions, helping staff to feel more comfortable working with an institutional standard, and students to enjoy a more successful SLA.

Since the traditional 'mother tongue prohibition' seems to have lost its stronghold, this research is based on the hypothesis that overall, L1 use could in fact be advantageous to Colombian EFL university students. The study aims to reach conclusions regarding the specific circumstances in which it might be beneficial or detrimental to students' SLA.

\section{Theoretical Framework}

Rinvolucri (Deller E Rinvolucri, 2008, p. 4) describes the "ban" on the L1 in the L2 classroom as "bizarre". But just exactly how bizarre is it? As one would perhaps expect, like most teaching strategies, there are both benefits and drawbacks to using the students' mother tongue in class. However, since it seems that students will use their L1 in the L2 classroom "whether we like it or not" (Harmer, 2007, p. 132), then we must consider when and how it should or should not be exploited, allowing it to become a help rather than a hindrance in the language classroom.

Drawing on others' research, Harmer (2007, p. 133) suggests that disadvantages of L1 use in class include i) reduced exposure to the L2 and therefore less opportunity for students to imitate authentic language, ii) difficulty for teachers to exploit students' L1 if they themselves do not speak that language, and iii) a lack of appropriateness in communicative speaking tasks. He also clarifies that it is important that there is always more L2 used than L1.

In contrast, Harmer also mentions advantages to L1 use, including i) drawing comparisons between the mother tongue and the target language, ii) improved group dynamics and classroom rapport, iii) concept checking through translation, and iv) more efficient class administration, "including learner training and giving feedback and evaluation" (ibid). Deller and Rinvolucri add to these advantages by suggesting that allowing, and indeed actively encouraging, the student L1 helps students to "feel safe and grounded in the English classroom" (2008, p. 10). They list several more benefits of L1 use, to both students and teachers, namely i) faster progress, especially at lower levels, ii) greater exploitation of higher level students' linguistic intelligence, iii) greater understanding of L2 grammar through the "MT grammar mirror", iv) clarity in learning new lexis, and recognising cognates and non-cognates in the $\mathrm{L} 1, \mathrm{v}$ ) the provision of an additional resource in the language classroom, vi) more opportunity to develop student autonomy, and vii) making the most of "limited linguistic resources". Cook (2001, p. 153) adds even further to this list by claiming that exclusive L2 use can "make the class seem less real".

\section{How Much?}

Back in 1987, Atkinson (1987, p. 242) suggested that an approximate ratio of $95 \%$ L2 vs. $5 \%$ L1 would be appropriate at lower levels, while Tang (2002) more recently increased this to $10 \% \mathrm{~L} 1$ at lower levels, which should then be reduced as learners' proficiency improves. Neither Atkinson nor Tang explain how such ratios could be achieved and maintained, or indeed measured in the first place. Supporting 
Tang's idea of reducing L1-use at higher levels of competence is Prodromou's 2002 study (cited in Ferrer, 2011), which finds that students do in fact rely less on their L1 as they become more proficient in the L2.

\section{Codeswitching}

It has been suggested for some time that codeswitching plays an important role in the process of bilingualism (Grosjean, 1982, p. 145), and Lluda claims that codeswitching could offer an alternative to classrooms that wish to avoid what is an "artificially monolingual communicative setting" (2004, p. 317). Cook also expresses support for codeswitching among people who speak two languages, claiming "there is not much point in being multicompetent if you are restricted by the demands of a single language" (2001, p. 105).

Despite the negative attitude often adopted towards codeswitching, even by code-switchers themselves (Grosjean, 1982, p. 146-8), Lluda refers to the work of several authors in describing the "recent appreciation of L1 use and codeswitching as a valuable pedagogical tool in the classroom" (2004, p. 317). Sert furthers this, claiming that in clarifying and transferring meaning efficiently in the L2 classroom, codeswitching constitutes "a useful strategy in classroom interaction" (2005, ITESL website).

Sert also warns, however, that codeswitching can have a detrimental effect on L2 learning, eventually preventing effective communication with native speakers of the target language (2005), proving Macaro's earlier claim that "there is nothing in the literature to suggest that codeswitching is harmful to language acquisition" (2001, p. 271) no longer true.

\section{Student Identity and Humanism}

The CEFR is very clear regarding the status of the learner's mother tongue, and culture, stating, "the learner of a second or foreign language and culture does not cease to be competent in his or her mother tongue and the associated culture" (Council of Europe, 2001, p. 43). Harmer echoes this sentiment to some degree, claiming that "our natural inclination to communicate in our mother tongue is non-negotiable; it is just part of what makes us 'us'" (2007, p. 132). Both Kavaliauskien and Carless agree that students' mother tongue is linked to their identity (2009, p. 3; 2008, p. 333). Tang refers to Nation's claims that L1 prohibition in class is often considered a degradation of the students' mother tongue, and as such has "harmful psychological effects on learners" (1990 in Tang, 2002).

O'Keeffe (2011) suggests that L1-use can help students relax, increasing their confidence, which in turn can increase motivation, and Mahmoud complements this, claiming that students use their L1 in class because it enables them to fulfill their "natural desire to communicate", which may otherwise be impeded by gaps in their $\mathrm{L} 2$ knowledge (2011).

\section{L1 in Groupwork}

One "social" or "affective" strategy used by learners when working independently of the teacher is to cooperate with their peers (O'Malley and Chamot, 1995, p. 46). Harbord suggests that at beginner levels, it is more advantageous "to allow students to [work together] thoroughly in the L1 than to do it tokenistically in the L2" (2008, p. 354). Atkinson (1987, p. 243) also finds it useful for students to use their L1 when working in small groups - a sentiment echoed both by Holliday (1994, in Carless, 2008, p. 331) and Kavaliauskienè (2009, p. 3). Carless does, however, warn that having students begin a task in groups without giving them the linguistic tools necessary to complete it, will inevitably lead to L1 use where it may not have been absolutely necessary (2008, p. 336).

\section{The (Non-)Native-Speaker Teacher}

Despite some recent effort to replace the term "Non-native speaker teacher" with the possibly more 
politically-correct "multilingual teacher" (Christison \& Murray, 2011, p. 24), the terms NEST -Native English Speaker Teacher- (Medgyes, 1994 in Johnson, 2008, p. 203) and its opposite, NNEST, are commonly-found in literature regarding TESOL. Since using "multilingual teacher" to refer to NESTS could be understood to imply that NNESTS are therefore monolingual (which is not necessarily the case), for the purpose of this paper, we will stick with the more traditional terms NESTS and NNESTS.

The role of NESTs vs. NNESTs has become a hot topic for debate in the field of ELT over recent years (Brown, 2007, p. 204), and the arguments both for and against are numerous (Cook, 2001, p. 188).

Despite the fact that most ESOL teachers around the world are non-native English speakers (Seidlhofer, 2000, p. 52), meaning the status of the NEST as "the only credible teacher of English is untenable" (Christison \& Murray, 2011, p. 23), according to Cook, "almost everywhere the native speaker is preferred" (2001, p. 175), especially in courses for international students within the Inner Circle (Christison \& Murray, 2011, p. 24). Atkinson suggests that "native speakers... often enjoy a disproportionate degree of status in languageteaching institutions" (Atkinson, 1987, p. 242), and Holliday refers to the obsession with native-speaker teachers as "native-speakerism" (2005, in Johnson, 2008 , p. 203). Harbord describes this issue as "a stumbling block to co-operation between local teachers and those sent from Britain", and suggests that British teachers use 100\% English while their "non-native-speaker colleagues" often "revert to" the L1 because they are "inadequately equipped with [the necessary] L2 strategies" to do otherwise (2008, p. 350). A teacher in Carless' study offers an alternative explanation, suggesting that "it is very strange and weird to speak in English when everyone can speak in [the L1]" (2008, p. 333), perhaps supporting Harmer's claim that human beings have a "natural inclination" to speak in their mother tongue (2007, p. 132).
While Cook claims that "the most obvious reason" for NESTS being favoured is the language model they can provide for students (2001, p. 175), Ellis points out that native speakers use special "foreigner talk... when addressing non-native speakers" (1997, p. 45), suggesting that this model is not necessarily any more authentic than that provided by non-native speakers. However, "the embodied linguistic/cultural capital of the native speaker" often still remains (Pennycook, 2010, p. 125).

Harbord suggests that some institutions avoid hiring NESTS because of their inability to explain the language system in the students' L1 (2008, p. 350), and both Llurda and Medgyes concur, emphasising how non-native speaker teachers are more able to guide students through the language learning process, as they have experienced it themselves (2004, p. 318; 1994 , in Johnson, 2008, p. 203). Llurda does concede however (albeit in a footnote, which appears almost as an afterthought), that native EFL teachers "who have been long-established in the local community and have learned its language" may also classify for this role as guide in the L2learning process (ibid, p. 321). Cook agrees that NNESTs' command of two languages may make them a better model for students (2001, p. 176).

While Cook implies that NESTS should be trained in students' L1 (2001, p. 154), Atkinson warns against those same teachers who do speak the local L1 a) thinking their command of said L1 is better than it actually is and/or b) using students to practice on or "show off" to (1987, p. 247).

\section{L1 in Teaching Grammar}

Cook (2001, p. 156) claims that the L1 can be useful in explaining grammar to students, particularly since grammar terminology will "make little sense" to beginner-level students. Opposing this view, however, is Harbord, who argues that such explanations "should ideally be 
conducted in English", claiming that the main reason teachers fail to do so is lack of training and therefore confidence in using L2 strategies to communicate the new language structure effectively (2008, p. 353).

Ferrer argues that with training in contrasting L1 and L2 grammars, students will go through a process of consciousness-raising and ultimately become more competent in both grammatical acccuracy and communication skills (2011). Lightbown and Spada's work supports his claims, suggesting that, particularly in homogeneous-L1 classes, contrasting the L2 form with that of the L1 could be necessary, to avoid over-generalisation of an L1 pattern (1999, in Ferrer, 2011).

\section{L1 in Teaching Vocabulary}

Snow states that teachers often find L1 translation the fastest way to explain new vocabulary, and suggests that while this should not necessarily cause guilty feelings, teachers should complement this with an additional presentation technique and always provide further context for the new language (1998, p. 24). Harbord (2008, p. 354), while agreeing that teachers and students may often translate lexemes into the L1 for ease or speed, suggests that this can easily lead to students forming bad habits, believing that word-for-word translation is a valid strategy, as opposed to Danchev's more desirable "functional translation" (1982, ibid, p. 354). McCarthy and O'Dell support Harbord's apprehension towards simple translation, warning learners that "it is not enough just to know the meaning of a word"; they claim that it is also essential students understand the new item's i) word associations, ii) grammatical characteristics and iii) its pronunciation (1995, p. 2). Cameron claims that although the immediate translation of lexical items can aid students' immediate comprehension, this does not ensure that the new language will be committed to their long- term memory, due to the absence of any deep processing (2001, p. 85).

Of the seven techniques described by Grauberg for teaching vocabulary, three exploit the L1, through word lists, flashcards or association with the sounds of the mother tongue in new target language vocabulary (1997, p. 20-1). Shin suggests using "visuals, realia and gestures" to explain new lexis to students when it is within the realm of comprehensibility at their level of competence, but using L1 support to explain more abstract concepts or phrases (2011). Harbord adds to Shin's alternative L2 strategies, offering "visual prompts, mime, and evoking situational context to create a need for the item in question (for eliciting), together with paraphrasing, definition, and multiple exemplification", as a more appropriate way of teaching language than resorting to the L1, though he also concedes that the use of L1 translation to check understanding is acceptable (2008, p. 354).

\section{Dictionary Use}

Particularly in institutions that still prefer maximum L2 exposure, "bilingual dictionaries are sometimes thought of as inferior to monolingual dictionaries, especially for advanced learners" (Berwick \& Horsfall, 1996, p. 12). While McCarthy and O'Dell's vocabulary self-study book states the importance "firstly" of an L2 monolingual dictionary, it does also recommend the use of a "good" bilingual dictionary (1995, p. 1). Similarly, although he recommends student use of monolingual dictionaries, Harmer also states "a good bilingual dictionary is very important for efficient language learning" (2007, p. 242). Neither of the above explains what constitutes a "good" bilingual dictionary.

In language production, Berwick and Horsfall claim that regardless of how useful the information in a monolingual dictionary might be, "if a student does not know the right word to 
look up, this information will remain hidden away" (1996, p. 13).

\section{Saving Time}

Despite Harbord emphasising that L1-use in class is definitely "not a device to be used to save time for 'more useful' activities" (2008, p. 355), Shin (2011) urges teachers to "consider using L1 when it is more important to spend time doing the activity rather than explaining it". Mahmoud agrees that using the L1 can limit "the waste of precious class time" (2011), and Cook suggests it can constitute a "short-cut in explaining tasks" (2001, p. 157).

\section{Improved Rapport}

Harmer (2007, p. 133) lists improved rapport and class dynamics as a reason to use the L1 in class, and Lynch also claims that speaking the local L1 "aids in developing rapport with your learners" (2011). Harbord though, believes that this will probably have "a fairly negative effect" on students' inclination towards using the L2 in class, and sees no reason not to use L2 strategies to build student-teacher rapport (2008, p. 354).

\section{Method}

\section{EFL context}

After analysis of the extensive literature published on L1 use in the language classroom, students and teachers in the EFL context were surveyed in order to establish current perceptions and practices, which in turn would act as a basic needs analysis for any future action at the institution. Teachers were asked about their knowledge of English and of the local language, as well as about their use of the local L1 in class. They were also asked about dictionary use. Students were asked about their perceptions regarding their teacher's language abilities, as well as their ideas about L1 use in class. They also responded to questions regarding their teacher's enforcement of an EOR (English-Only Rule).

Carrying out a written survey with teachers meant that all data could be collected at once, saving time (Seliger \& Shohamy, 1989, p. 172), and allowing any queries that arose to be resolved immediately by the researcher. Although there was no institutional rule in place regarding the use or avoidance of the L1 in class, the researcher felt that her position as teachers' immediate superior could have an effect on the honesty of their responses; therefore, surveys respected full anonymity, in order to allow teachers to respond more freely (Seliger \& Shohamy, 1989, p. 172). Most questions were closed, to allow for more efficient analysis of the data yielded (Nunan, 1992, p. 145), though multiple-choice responses included an "other" option for freer responses, and some open questions were also included.

A stratified random sample (Dornyei, 2003, p. 73) of students was taken from the university population to survey; individuals were approached around the university campus and asked two initial questions to establish their suitability to participate in the interview: i) "Do you study here?" and ii) "Have you ever studied English here?" A need to respect students' time during exam period meant that the student survey was administered as a one-to-one structured interview. This also encouraged more students to participate and answer all questions, given their "personal involvement with the interviewer" (Johnson, 1992, p. 115). A mix of open and closed questions were asked, in students' L1, to help respondents feel comfortable and more able to understand and respond fully (Seliger $\varepsilon$ Shohamy, 1989, p.172).

\section{ESL context}

Among the many "generic labels" (Spack, 1997 cited in Pennycook, 2010, p. 145) found in the world of ELT, we find EFL and ESL; although 
these terms may be considered interchangeable or even replaceable by the "encompassing" English as an "additional language" (Hall et al, 2011, p. 198) since many strategies and resources apply to both, there are also some fundamental differences between the two (Bell, 2011). Perhaps the most relevant of these differences here, is the fact that EFL students tend to share the same L1 within any one group, whereas this is not the case in the ESL setting (Hall et al, 2011, p. 198). This means that while the learners' L1 is often the "vehicle for learning and teaching" in the EFL setting (ibid, p. 199), it is simply not an option in the ESL context (Cook, 2001, p. 153; Christison E Murray, 2011, p. 52). Taking this difference into account, this study considered whether lessons might be learned from an ESL setting, regarding strategies for encouraging greater L2 use in the EFL context.

In order to maintain specific relevance to the home university demographic, the factors of age and degree program were controlled (Hatch E Farhady, 1982, p. 16) by studying higher education courses that included mixed-faculty groups. A triangulation technique (Wallace, 1998, p. 36) consisting of student and teacher surveys, as well as live class observations, was implemented in a UK university, in order to study successful pro-L2-use strategies employed in the heteregeneous-L1 context. Mirroring the surveys carried out in the EFL context, the ESL teachers were also asked about their knowledge of English and of any other languages, as well as about their use of their students' L1 in class. They, too, were asked about dictionary use. The ESL students were also asked about their perceptions regarding their teacher's language abilities, as well as their ideas about using their L1 in class. They, too, responded to questions about EOR enforcement in class. Class observations allowed the researcher to monitor further the L1/L2 strategies actually used (or not used) in class, by both teachers and students, in order to corroborate or refute the findings from the surveys.

Although one-to-one interviews can be timeconsuming for the researcher (Johnson, 1992, p. 114), the small sample size of ESL teachers in this case made the task manageable. Interviews were semi-structured, and, as in the EFL surveys, asked a mix of open and closed pre-designed questions with space for "other" responses in multiple-choice items.

The sample of ESL students was one of convenience (Dornyei, 2003, p. 72); it included $100 \%$ of students present in the ESL courses running at the time of survey in the same university department. Since students spoke different mother tongues, this could not be used for the survey, as had been done in the EFL context. The survey was therefore applied with students in the upper two levels of proficiency only, to ensure full respondent comprehension and therefore validity of the instrument (Johnson, 1992, p. 114). Questions were once again a mix of open and closed items, offering "other" options as part of multiple-choice responses.

As Freeman and McElhinny found in their study on male-female class participation, student and teacher perceptions of what happens in the classroom do not always coincide fully with reality (in McKay and Hornberger, 1996, p. 262). In order to decrease the margin of error due to such misconceptions, teacher and student surveys were complemented with live class observation. The participating UK university agreed to allow one observation per course, giving a total of three. Each lesson lasted approximately 105 minutes.

To focus class observations and help the observer maintain objectivity (Wajnryb, 1992, p. 8), a pre-designed task was used, which allowed the researcher to focus on i) details of any instances of student L1 use (by teacher or 
students), ii) details of any situations where the L2 was not sufficient to ensure the occurrence of effective communication, iii) the outcome of any situations as described in i) and ii), and iv) the overall sense of teacher-student and student-student rapport, based on Harmer's point that together with group dynamics, this is often considered one of the benefits of using students' L1 in the classroom (2007, p. 133). Thus, the observer could categorize notes in situ, which would in turn facilitate the data analysis stage.

\section{Findings \& Discussion}

\section{Teachers}

Most of the EFL teachers are native English speakers, perhaps confirming Cook's claim that they are preferred in institutions in most parts of the world (2001, p. 175). However, these teachers also appear to have a working knowledge of the local language, with only two teachers assessing their own proficiency to be anything less than advanced. Students' perception of their teachers' language level is similar, and the fact that only $4 \%$ of students claimed not to know their teacher's level of competence in Spanish suggests that most students have heard their teacher speak in the local L1 at some point. If we agree with Llurda's idea (2004, p. 318) that those native speaker teachers who have lived locally and learned students' L1 can serve as a role model for learners, just as non-native English speakers can, then these teachers are in a position to help students in their learning. The remainder of these teachers have learned English (and often Spanish) as a foreign language, suggesting that they are equally as good role models for students.

All three of the ESL teachers are native English speakers, perhaps confirming Christison \& Murray's claim that NESTS are preferred in inner circle international courses (2011, p. 24). Two of these teachers speak Spanish and/or
French, which are not common L1s among the students. French is a common additional language among students in the level 3 group, however, and therefore could constitute an opportunity for L1 use between teacher and students. All three teachers believe, though, that this would exclude other students and therefore is not a desirable tool to use in the heterogeneous-L1 classroom. One of the teachers speaks no foreign languages, which, according to Cook (2001, p. 154), might disqualify her as a role model for language learners in her class.

In the ESL context, $76 \%$ of the students prefer to have a teacher who does not share their mother tongue, as this forces them to practice the L2. For those who did prefer a teacher who shared their L1, many agreed with the EFL teachers surveyed, as well as with Medgyes (1994, in Johnson, 2008, p. 203) and Cook (2001, p. 175), that this can help teachers to understand students' problems better, and to act as language learner role models, as well as to make L1 comparisons and speed classes up.

\section{L1 Use}

Since $93 \%$ of the mixed-L1 team of EFL teachers already use Spanish in their classrooms, this clearly contradicts the situation described by Harbord, in which only the non-native speaker teachers use the L1 in class, as opposed to the 'English Only' native speaker teachers (2008, p. 350). These EFL teachers use students' L1 more at lower levels, which might surprise Deller and Rinvolucri, who, in their 2008 book of activities to exploit students' mother tongue, mark most activities as suitable for intermediate and advanced students, but only a third for beginners.

The EFL teachers are falling into the trap described by both Snow and Harbord (1998, p. 24; 2008, p. 354), using students' L1 mostly to translate lexis, because it is quicker and easier than using the L2. While teachers should not 
necessarily be made to feel guilty about this (Snow, 1998, p. 24), they may need to use more L2 vocabulary-teaching strategies, such as gesture, paraphrase or giving examples, (Shin, 2011; Harbord, 2008, p. 354). The ESL teachers use some of these strategies (ibid), as well as peer explanation, dictionaries or one-toone work that could also be useful in the EFL context. In particular, they are seen to use various L2 strategies to clarify instructions for students, perhaps reinforcing Harbord's point (2008, p. 353) that teachers (whether ESL or EFL) should not need to resort to using the L1 for this purpose.

Despite the ESL teachers echoing McCarthy and O'Dell's recommendation that students use a monolingual dictionary in the first instance (1995, p. 1), they do not provide students with this tool in class, and less than half of the ESL students surveyed use one. This is also true for the use of bilingual dictionaries, mirroring the overall lack of use of dictionaries in the EFL context, and perhaps suggesting a need for more training and/ or resources in this area. However, the dictionary use observed in the ESL setting was interesting; when students encountered unknown vocabulary in the L2, they looked it up in a monolingual electronic dictionary, before sharing the new information with other students, and in one group, the whole class became involved in decoding the meaning, including the teacher. While this process may take longer than the frequently-revered quick and efficient L1 translation (Harbord, 2008, p. 351), it does provoke discussion in the L2, with students using the type of functional language described by Brown (2007, p. 229-30) in English to reach a common goal. This L2 metalanguage, or "classroom language" (Brown, 2007, p. 229), is used quite naturally among students in the ESL groups, suggesting that EFL students could and perhaps should do so too.

Although concept-checking questions were "developed specifically for use in multilingual classes" (Atkinson, 1987, p. 243), they were not used during any of the three ESL class observations. Nor, however, was the L1 used to check students' understanding (Thornbury $\varepsilon$ Watkins, 2007, p. 26), suggesting that perhaps the ESL teachers were simply skipping the step of checking understanding altogether, rather than consciously employing any particular pro-L2 strategy. The ESL students, on the other hand, are seen engaging in concept checking with their peers or teacher in English, and while this may appear to fall into the desirable category of students using effective L2 metalanguage, what is also observed is that after L2 concept checking, a) one student seems equally (if not more) confused, and b) another student then re-clarifies in the mother tongue with an L1-sharing peer. While it is clear that in the case of the multilingual ESL setting where a student does not share their L1 with peers, concept checking must be carried out in the L2, it does beg the question as to why this could not be done in the L1 where possible (i.e. in the EFL setting).

L1 use in the ESL students' own notes and for dictionary work is lower in the higher level class, suggesting that L1 reliance may well decrease as students' L2 competence increases, confirming Prodromou's 2002 findings (Ferrer, 2011).

Most of the EFL teachers claim to allow their students to use the L1 in class to encourage students' natural thought processes and creativity, as well as for speed and ease. Although most teachers believe that students' main purpose in using the L1 is to clarify grammar concepts, only half allow them to use Spanish to communicate with the teacher. Despite Harbord's warning that grammar classes should be led in the target language (2008, p. 353), it seems that teachers should perhaps heed the advice of authors who support the use of L1 in grammar training, in order to avoid complicated terminology (Cook, 2001, p. 156), and help students to become 
aware of similarities and differences between the two language systems (Ferrer, 2011; Lightbown E Spada, 1999 in Ferrer, 2011). Students would probably find more accurate clarification on grammar issues from their teacher than from their peers.

Although the ESL teachers believe it is wrong to use students' L1 in a heterogeneous-L1 context, they all claim that they would indeed exploit this resource in a monolingual setting. Firstly, while Harmer believes it is mankind's "natural inclination" to use one's mother tongue (2007, p. 132), similarly, the ESL teachers believe that it would be a natural reaction to use students' L1 if they were able to. Secondly, like the EFL teachers, they support both Mahmoud's and Cook's idea that L1 can save time in class (2011; 2001, p. 157). Thirdly, the ESL teachers echo O'Keeffe's claim (2011) that using the common L1 would help students to relax and feel comfortable in the classroom.

A slight difference can be seen in perceptions between EFL teachers and their students regarding teacher L1 use. Although most students agreed that their teacher had used the L1 in class, they thought that this had been more for grammar than for vocabulary teaching, and other purposes such as discipline and administration were mentioned as much as vocabulary.

In terms of student L1 use, the EFL students agreed that almost everyone used the L1 in class, mostly among themselves. Although clarifying grammar concepts was one of the main purposes for student L1 use, as teachers believed, according to students, the purpose was more often social, echoing Griffiths and Parr's findings that students sometimes use different learning strategies to those teachers believe they are using (2001, in Harmer, 2007, p. 395-6). Most students use the L1 in class due to a lack of ability or knowledge in the L2 (see Figure 1), suggesting that perhaps they need training in further communication strategies, such as those described by Atkinson (1987, p. 245).

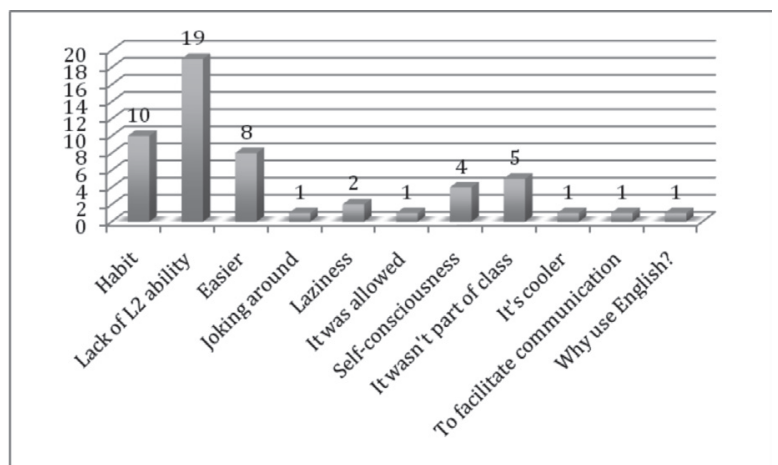

Figure 1: Why EFL students use the L1 in class

In the ESL context, several languages were shared by students in each class, as either their first or additional language; the level 1 group had the possibility of seven languages being spoken in class in addition to English, while the level 2 group had 12 other possibilities for language use, meaning that English was not always the only common language among students, nor their only possibility for communication, as we might assume to happen in most ESL contexts (Bowen, 2011). This information can be seen in figures 2 and 3 below.

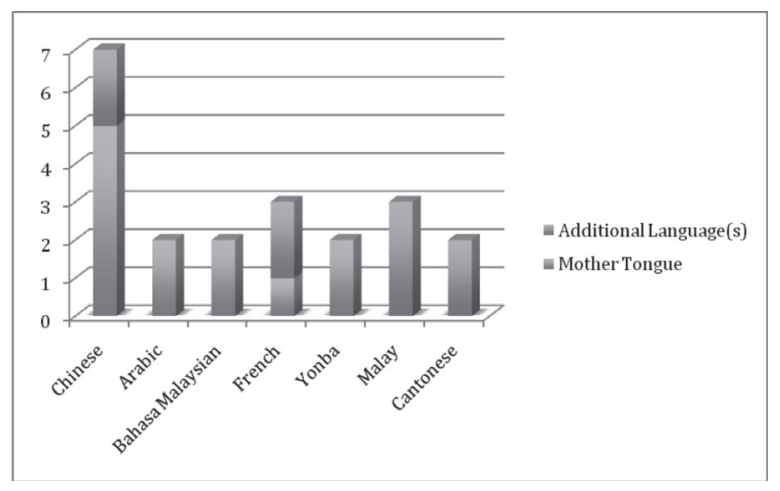

Figure 2: Languages spoken in ESL level 1 group

This means that while students use mostly English in the classroom, two thirds also use their L1 to some degree. Most use it with their classmates, regardless of whether this means excluding non- 


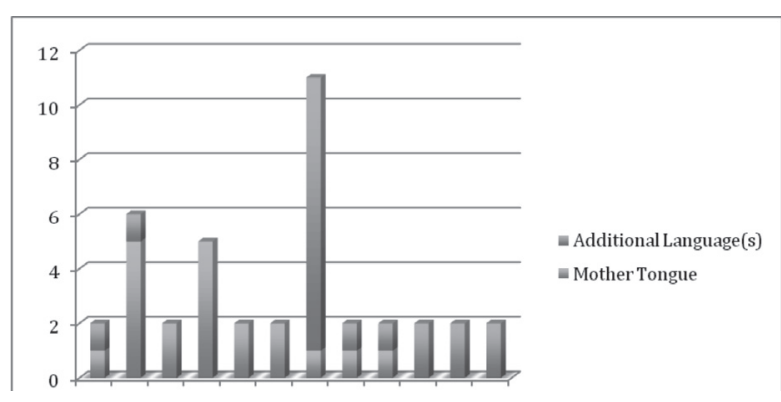

Figure 3: Languages spoken in ESL level 2 group

speakers of that language around them, or in their own heads, perhaps taking Macaro's "soft option" of thinking in the mother tongue rather than making an effort in the L2 (2001, p. 103-5).

According to the ESL students, translating vocabulary constitutes a large part of the $L 1$ use in the lower level class, and remains relatively important in the higher level too, as is the case for checking information with classmates. Live observation confirmed that students in all three groups used the L1 to understand new L2 vocabulary.

Despite students claiming that L1 use for informal socializing was more of an issue at higher levels (this may be because there are more L1-sharers in this group), this phenomenon was observed in all three class observations, mostly before class began. While two teachers made no reaction to the pre-class L1 chatter, the other's EOR began from entering the room, and a monetary fine was threatened (though seemingly not executed). Very few of the ESL students use the L1 to compare grammar structures with the L2, but it is not known if this is due to the lack of a need to do so, or perhaps their lack of training to do this. What is clear from this study is that students' main reason for using the L1 in class is pure habit, suggesting more training is needed in this area.

Overall, the ESL students believe that the L1 should not be used in the classroom, as this can hinder their learning of the L2. If used at all, they believe it should be minimal, and only in lowerlevel classes, to aid natural self-expression. While these beliefs coincide to some extent with those of the teachers, only two students mentioned vocabulary as an area where the L1 would be useful, as opposed to the majority of teachers, suggesting that this need may not be as strong as teachers believe.

The idea held by several authors that the L1 can be useful to students when working in small groups (Atkinson, 1987, p. 243; Holliday, 1994, in Carless, 2008, p. 331; Kavaliauskien , 2009, p. 3) is reinforced through the ESL observations, which saw students using the L1 during groupwork. This went unnoticed by the teacher; perhaps due to large class sizes and/or a need for closer monitoring. Teachers tend to form new student groups within the class, meaning that L1-sharers are usually separated. While this would not have the same effect in a monolingual EFL context, it may separate friends, which in turn could avoid the 'social chit-chat' element of L1 use in class and encourage more L2 output.

Despite Harmer's suggestion that the L1 can be used to improve rapport and class dynamics (2007, p. 133), the rapport between both teacher and students and among students in the ESL classes appeared to support Harbord's view (2008, p. 354) that this can indeed be built through the L2.

Those students who tended not use the L1 in class did so of their own volition, making a conscious choice to improve their English in this way. The teachers' EOR appeared to have little effect, with only a fifth of the L1-avoiders stating this as their reason. In fact, students are generally unaware of a 'rule' existing, although they do see their teacher encouraging them to speak in English as much as possible and explaining their reasons for this request. 


\section{EOR Enforcement}

Other than simply being asked and reminded by teachers to speak in English, the other teacher strategies most commonly recalled by students in the EFL setting involve punishments and scolding; not exactly the 'humanistic approach' to teaching that we would perhaps expect in today's classrooms. While two of the ESL teachers' strategies to enforce the EOR coincide with those of the EFL teachers (i. reminding students to speak English and ii. monetary fines), the remaining three strategies mentioned are perhaps somewhat more humanistic in their execution (i. humor, ii. discrete presence and iii. explaining to students the logic behind the rule). The ESL students confirmed this, naming nine pro-L2 teacher strategies, only one of which involves a 'punishment' element (a monetary fine), which is perhaps why there was no evidence of the students feeling that their own languages were being degraded in any way, as the L1 prohibition can do, according to Nation (1990 in Tang, 2002). The lack of more embarrassing punishments among the ESL teachers' strategies may constitute a different approach to that used in the EFL context, or could be attributable to the fact that the ESL teachers were interviewed on a one-to-one basis, whereas the EFL teachers were surveyed anonymously.

\section{Conclusions}

Although no official EOR (English Only Rule) is in place at this Colombian university, most students feel that it is in fact imposed in class. Despite this, most of the EFL teachers claim to use and allow Spanish to some degree in their classes, particularly with lower-level groups. While students believe Spanish is used by the teacher mostly for teaching grammar, teachers claim to use it mostly for teaching vocabulary, and do so for ease and speed. Similarly, while teachers believe that students use their L1 most to discuss grammar points, students claim to use it more for socialising, although grammar is an additional purpose. Students use the L1 because they feel unable to express themselves in the L2, but believe that it should only be allowed in extreme cases, as they believe they need to practice and interact in the L2 to learn more quickly. In addition to reminding students to speak in English during class, teachers use a number of disciplinary measures to enforce the EOR in class.

Conversely, in the ESL setting, an institutional EOR is in place, and teachers use several techniques to enforce it, ranging from humor, detailed explanations and further academic support to monetary fines. L2 strategies used by teachers to communicate with students include rewording, providing greater context or showing images. Although they recommend using dictionaries, teachers do not provide them, and while most students claim not to use one, some use of electronic L2-monolingual dictionaries is observed in class. As in the EFL context, most ESL students also use their L1 in class. While, like the EFL teachers, the ESL teachers believe that students use the L1 to clarify grammar concepts, again, students' perceptions differ, as most claim to use it to discuss vocabulary and to socialize. Class observations do see the L1 being used for socialising before class begins, but the L2 used to decipher new vocabulary. Students claim to use the L1 through habit more than for any other reason. Although rapport in the ESL classes appears to be good, teachers believe that L1-use might help students feel more relaxed in class; they also believe that this would save time over the course.

Overall, practices and perceptions are remarkably similar between the EFL and ESL settings. Students in both contexts flout the EOR, albeit slightly differently, and although the ESL teachers cannot use the student L1(s) in class, they consider it beneficial in a monolingual 
setting. The strategies employed by teachers to enforce the EOR are perhaps what differ most between the two contexts.

\section{Pedagogical Recommendations}

Before teachers "blame" all of their students' problems in the L2 on the negative influence of their mother tongue (Cook, 2001, p. 15), perhaps they should consider the findings of this study, which support Deller's claim that the student L1 is an "important resource" (2008, p. 3) in L2 teaching and learning. Teachers should be open to a certain amount of codeswitching in class, which can help avoid the "artificially monolingual communicative setting” (Lluda, 2004, p. 317).

In creating departmental guidelines, it is not only teachers' practice that must be considered, but also their perceptions, that is, that minimal L1 use does have a place in the classroom, particularly in lower levels, and especially in teaching grammar and vocabulary, as this can save precious time over a course.

\section{Levels}

In accordance with teacher and student perceptions, and with Harmer's advice (2007, p. 133), allowing students to use some L1 at lower levels may be beneficial to their $\mathrm{L} 2$ learning. This should be allowed less as students progress, so they can become more independent L2 users, employing more 'real-life' communication strategies such as circumlocution or paraphrase (Atkinson, 1987, p. 245). The L1 can still be useful at times in higher levels, particularly in comparisons or translations (Harmer, 2007, p. 133).

\section{EOR}

This study confirms that students use their L1 in class, irrespective of any EOR. Where institutional regulation demands the existence of an EOR, teachers can follow Harmer's advice to negotiate rules with students regarding acceptable use of the L1 and stick to them (2007, p. 133).
Any EOR-enforcement should employ more humanistic strategies such as those encountered in this study's ESL context, supporting Harmer's call for encouragement and persuasion (2007, p. 133) over the more humiliating and demotivating strategies of chastising or punishing students often used in EFL.

\section{Dictionaries}

While the monolingual dictionary is undoubtedly a valuable tool (McCarthy \& O'Dell, 1995, p. 1), its bilingual counterpart should not be prohibited in the classroom. Particularly in production, students may never find the lexical item they require if prohibited from using their L1 to look it up in a bilingual dictionary (Berwick $\mathcal{E}$ Horsfall, 1996, p. 13). As observed in the ESL setting of this study, electronic dictionaries may be more popular and/or practical among students than paper-based versions in today's classroom.

\section{Concept-Checking Questions}

This study supports Harmer and Harbord's claim that L1 translation is a valid technique to check understanding (2007, p. 133; 2008, p. 354), and suggests that it be encouraged in the EFL context as such, albeit alongside alternative L2 checking techniques.

\section{Groupwork}

This study witnesses even ESL students using their L1 during groupwork, where they share the mother tongue with peers. Not only is it natural for both EFL and ESL students to do so, many authors consider it useful too (Atkinson, 1987, p. 243; Holliday, 1994, in Carless, 2008, p. 331; Kavaliauskien , 2009, p. 3), particularly at lower levels, where attempts at groupwork exclusively in the L2 is more "tokenistic" than valuable (Harbord, 2008, p. 354). EFL teachers should therefore avoid insisting on 'English Only' during groupwork, other than in purely communicative activities, when students should be given all linguistic tools necessary to carry out the task before embarking upon it (Carless, 2008, p. 336). 


\section{Time Management}

Most EFL teachers in this study who use the L1 in class do so for ease or speed, and while this can help lower-level students to learn more quickly (Deller E Rinvolucri, 2008, p. 10), it is not always suitable, and should not constitute the easy way out for lazy teachers. The ESL teachers in this study offer many other strategies that teachers can use instead of relying on the L1, that provide students with greater exposure to the L2 and stimulate more deep internal processing leading to a more complete learning process (Cameron, 2001, p. 85). Such strategies include the use of visuals, paraphrasing or examples, echoing suggestions from Shin and Harbord (2011; 2008, p. 354), as well as peer explanation, dictionary use or teachers working one-to-one with individual students.

\section{Teachers' Knowledge of Local L1}

In this particular EFL team, which includes mostly native English speakers, teachers should be trained in the local L1, as suggested by Cook (2001, p. 154). This will empower them in class, as well as in their everyday life in Colombia. Teachers must not, however, over-estimate their ability in Spanish, nor use students to practice on (Atkinson, 1987, p. 247).

A teacher's status as a native or non-native speaker should not be taken into account at the hiring stage; the ability to use (and teach) the language proficiently is of more importance, in the case of both NESTS and NNESTS (Llurda, 2004 , p. 318). As shown in Deller and Rinvolucri's activity book to exploit students' mother tongue in the classroom, different types of activity can be used depending on the teacher's own level of proficiency in this language (2008, p. 11).

\section{Striking the Balance}

Previous research suggests that 5-10\% use of L1 in lower level classes is acceptable
(Atkinson, 1987, p. 242; Tang, 2002), and the EFL students in this study agree with both Tang (ibid) and Prodromou (2002, in Ferrer, 2011) that this proportion should decrease as students' competence increases.

Since an accurate measurement of the L1L2 ratio may be difficult to ascertain, the best option for EFL teachers may be to follow Harmer's advice that "most students are speaking English most of the time" (2001, p. 133), and refer to the popular term "judicious" to describe teacher and student use of the L1 in the classroom (Ferrer, 2011).

\section{References}

Atkinson, D. (1987). The mother tongue in the classroom: a neglected resource? ELT Journal. 41(4), 241-247.

Bell, K. (2011). How ESL and EFL classrooms differ. Retrieved 23 Sep 2012: OUP ELT Global Blog http:// oupeltglobalblog.com/2011/07/12/how-esl-and-eflclassrooms-differ/.

Berwick, G \& Horsfall, P. (1996). Making effective use of the dictionary. Pathfinder Series No. 28. London: Centre for Information on Language Teaching and Research.

Bowen, T. Teaching approaches: Using L1 in class. Retrieved December $16^{\text {th }} 2011$ from Macmillan's One Stop English website: http://www.onestopenglish. com/support/methodology/teaching-approaches/ teaching-approaches-using-11-in-class/146496. article

Brown, H. D. (2007). Principles of language learning and teaching. New York: Pearson.

Cameron, L. (2001). Teaching languages to young learners. Cambridge: CUP.

Carless, D. (2008). Student use of the mother tongue in the task-based classroom. ELT Journal, 62 (4), p.331-338.

Christison, M.A. \& Murray, D.E. (2011). What English language teachers need to know. Vol 1. Understanding learning. New York: Routledge.

Cook, V. (2001). Second language learning and language teaching. London: Arnold. 
Council of Europe (2001) Common European Framework of Reference for languages: Learning, teaching, assessment. Cambridge: CUP.

Deller, S \& Rinvolucri, M. (2008). Using the mother tongue. Surrey: Delta.

Dornyei, Z. (2001). Motivational strategies in the language classroom. Cambridge: CUP.

Dornyei, Z. (2003). Questionnaires in second language research. New Jersey: Lawrence Erlbaum Associates.

Ellis, R. (1997). Second language acquisition. Oxford: OUP.

Ferrer, V. (2011). The mother tongue in the classroom: Cross-linguistic comparisons, noticing and explicit knowledge. Retrieved November 14 $4^{\text {th }}$ 2011: www. teachenglishworldwide.com

Freeman, R and McElhinny, B. (1996). Language and Gender, in Sociolinguistics and Language Teaching. Edited by McKay, S. L. and Hornberger, N. H. Cambridge: CUP.

Grauberg, W. (1997). The elements of foreign language teaching. Clevedon: Multilingual Matters.

Grosjean, F. (1982). Life with two languages. An introduction to bilingualism. Boston: Harvard.

Hall, C.J, Smith, P.H \& Wicaksono, R. (2011). Mapping applied linguistics. Oxon: Routledge.

Harbord, J. (2008). The use of the mother tongue in the classroom. ELT Journal. 62(4), 331-338.

Harmer, J. (2001) The practice of English language teaching. Essex: Pearson Education.

Harmer, J. (2007) The practice of English language teaching. Essex: Pearson Education.

Hatch, E \& Farhady, H. (1982). Research design and statistics for applied linguistics. Massachusetts: Newbury House Publishers.

Hedge, T. (2000). Teaching and learning in the language classroom. Oxford: OUP.

Johnson, D.M. (1992). Approaches to research in second language learning. New York: Longman.

Johnson, K. (2008). An introduction to foreign language learning and teaching. Harlow: Pearson Education.

Kavaliauskien, G. (2009). Role of mother tongue in learning English for specific purposes. ESP World, 1 (22), Vol 8. Retrieved 23rd November 2011:http:// www.esp-world.info

Llurda, E. (2004). Non-native-speaker teachers and English as an international language. International Journal of Applied Linguistics, 14 (3) p.314-323.
Lowes, R \& Target, F. (1998). Helping students to learn. A guide to learner autonomy. London: Richmond.

Lynch, L. Should TEFL teachers be bilingual? Retrieved November 222011 from the ESL Base website: http://www.eslbase.com/articles/bilingual

Macaro, E. (2001). Learning strategies in foreign and second language classrooms. London: Continuum.

Mahmoud, A. (2006) Translation and foreign language reading comprehension: A neglected didactic procedure. English Teaching Forum, 44. (4) p.28-40.

McCarthy, M. \& O’Dell, F. (1995). English vocabulary in use. Cambridge: CUP.

McDonough, S. (1995). Strategy and skill in learning a foreign language. London: Edward Arnold.

Nunan, D. (1992). Research methods in language learning. Cambridge: CUP.

O'Keeffe, R. (2011). Towards a principled use of L1. HLT Magazine, retrieved 21st November 2011:http:// www.hltmag.co.uk/oct11/sart01.htm

O’Malley, J.M. \& Chamot, A.U. (1995). Learning strategies in second language acquisition. Cambridge: CUP.

Pennycook, A. (2010). Critical applied linguistics: A critical introduction. New York: Routledge.

Seidlhofer, B. (2000). Mind the gap: English as a mother tongue vs. English as a lingua franca. Vienna English Working Papers, 9 (1) p.51-68.

Seliger, H. \& Shohamy, E. (1989). Second language research methods. Oxford: OUP.

Sert, O. (2005). The functions of code switching in ELT classrooms. The Internet TESL Journal, XI,(8), Retrieved $1^{\text {st }}$ June 2011: http://iteslj.org/Articles/ Sert-CodeSwitching.htm

Shin, J.K. Ten helpful ideas for teaching English to young learners. English Teaching Forum, 44. (4) p.2-13.

Snow, D. (1998). Teaching and learning vocabulary. Pathfinder series No. 34. London: Centre for Information on Language Teaching and Research.

Tang, J. (2002). Using L1 in the English classroom. English Teaching Forum. 40, (1) p.36-43.

Thornbury, S. \& Watkins, P. (2007). The CELTA course (trainer's manual). Cambridge: CUP.

Ur, P. (2004). A course in language teaching. Practice and theory. Cambridge: CUP.

Wajnryb, R. (1992). Classroom observation tasks. Cambridge: CUP. 
Wallace, M.J. (1998). Action research for language teachers. Cambridge: CUP.

Wang, W \& Wen, Q. (2002). L1 use in the L2 composing process: An exploratory study of 16 Chinese EFL writers. Science Direct website, retrieved 23rd November 2011 from: http://www.sciencedirect. com/science/article/pii/S106037430200084X

\section{THE AUTHOR}

JILL FORTUNE, after completing a first degree in Hispanic Studies at the University of Sheffield (UK), started working as an EFL teacher in Spain. A few years later, she moved to Colombia, where she began working at the Externado University. Having completed a CELTA course, she graduated from the MA in TESOL from Sunderland University (UK) in 2011. She still works at the Externado University, as both an EFL teacher and Language Department Coordinator. She has carried out projects regarding L1 use in the classroom, the successful exploitation of modern television series in EFL, and learner autonomy, among others. 